\title{
A Qualitative Evaluation on Fiqh Education from İmam Hatip High Schools to Theology Faculties
}

\author{
Samira Hasanova ${ }^{*}$ \\ Near East University, Faculty of Teology, Nicosia-99280, North Cyprus
}

\begin{abstract}
Fiqh (Islamic law) has a central place in religious education. This paper attempts to attract attention to the central position of fiqh, which is defined as knowing one's rights and duties; for this purpose the historical background of fiqh education from Ottoman madrasahs to the present is briefly covered, and its relation with basic Islamic sciences and Arabic, which is known as instrumental sciences, is displayed in the context of quality of education. In the paper the negative and positive aspects of the reflection of acquisitions on faculty education of İmam Hatip high school graduates in the case that they enter theology faculty are examined. Fiqh is related to such disciplines as construction, hadith and kalam based on religion; but it is also connected with such disciplines as philosophy, sociology and psychology which are not based on religion. The paper emphasizes the importance of including new fields such as Islamic law sociology and Islamic law philosophy in theology curricula and discussion is made on the necessity to open a space in the curriculum for these fields. The purpose here is to examine the problems in fiqh education in the process from İmam Hatip high schools to university and evaluate them from the perspective of students, lecturers and the curriculum.
\end{abstract}

\section{Introduction}

\subsection{Purpose}

The purpose of my study is to question the quality of fiqh education, which is also known as Islamic law. The reason is my concerns about the adequacy of the acquisitions of individuals who graduate from İmam Hatip High Schools and prefer Theology Faculties. I aim to analyze and explore the reasons of the problems I encounter as someone who gives fiqh education at Theology Faculty.

\subsection{Method}

The paper follows literature review and on-site monitoring/case analysis method.

\footnotetext{
*Corresponding author: samira.hasanova@neu.edu.tr
} 


\section{Fiqh and its place in Islamic sciences}

In the geography that we live, we sometimes witness rising tensions, conflicts and disagreements. It is a reality that these disagreements and conflicts are based on religion. However, we cannot claim that religion is the reason of these conflicts. Misunderstandings in the interpretation of religion lead to wars and conflicts. If we talk about the special case of Islam religion, we can say that it consists of three main elements: Belief/kalam, deeds/fiqh and ethic/sufism. It should be noted that understanding and teaching these three elements as a whole is an important step in terms of preventing possible conflicts. Different schools have occurred in our tradition concerning the understanding of the three elements of religion. These schools were formed in a systematic and consistent manner as a result of an intellectual mental activity; at the same time they are responses to the different interpretations in their ages. Maturidi and Eşari schools which were formed in the field of belief are expressions of a stance towards other salafi, exotic and dissenter schools. The same also goes for fiqh sects. There are several reasons for the fact that some sects are accepted and some have become materials of history in our tradition. However, we can say that the search for social peace is effective in the mentioned preference. Religious-based conflicts in our region are connected to the past in terms of origin and mentality and they are not new interpretations. Therefore, we have to understand the experience that our tradition produces against the understandings which lead to conflict and wars and transfer it to generations. Religious education and its quality bear huge importance in terms of protecting our generations from this kind of conflicts.

Knowing the Islamic laws in any manners or ways with self-diligence. Base on curriculum of Islamic school, Fiqh is the field of Islamic study which is designed to prepare students to recognize, appreciate and practice the Islamic law, which later became the basis of life view through the activities of counseling, instruction, training and experience practice. Based on the explanation above, the authors concluded that the jurisprudence is a science in the Islamic Shariecah which specifically discuss the issue of Islamic rules which is relating to the person, either permitted or forbidden and compulsory or permissible and human relationships with each other, based on postulates of the verses of Al Qur'an and Sunnah of the Prophet[1].

Fiqh, on the other hand, is a discipline which regulates, directs and manages the behaviors of Muslims. Almost all of the religious knowledge obtained from main sources with mental effort is figh; it is also called the knowledge of rights and liabilities of a person. Fiqh is the name of the science which consists of knowledge and judgments on the descendants of religion and practical life and until today catechism, law and its methodology, economics, politics, administrative sciences and institutions related to these sciences have been seen and examined in fiqh branch among Islamic sciences. Fiqh is the changing aspect of the changing face of Muslim world; to tell the truth, it is the changeable aspect. This is to say that fiqh consists of prayers, transactions and punishments. Prayers is the unchanging aspect of fiqh as its boundaries are determined in Qur'an and Sunnah and it cannot change. Transactions is the part which regulates interpersonal relations. This is the part which changes with time, place and circumstances. In other words, this is the part which adapts to the changing worlds and innovations. Fiqh procedures sciences, which is not in Qur'an and Sunnah or, even if it is in Qur'an and Sunnah but is required to give new judgments in the face of new conditions, is also known as fiqh methodology and is now a part of fiqh. Fiqh procedures also serves as the sociology and philosophy of fiqh. Therefore, in order to know a fiqh science branch, one has to know the elements which constitute the content of fiqh very well. As our main sources are in Arabic, one has to have good command of Arabic language naturally in order to be able to read Fiqh. 
In general it can be said that the study of Islamic knowledge cannot be separated from the Arabic language. The great body of work on Islamic knowledge that are used as main references or considered to be important work are almost all written in the Arabic language and text. Therefore, the mastery of the Arabic language is a prerequisite for those who wish to study Islam from its original sources. Among the problems faced by lecturers involved in this research is the university students' weak grasp of the Arabic language. Most of the reference books used by lecturers are almost entirely in Arabic. It would be fair to say that there are no precise, concise and in depth literature on usul al-fiqh available in other languages besides Arabic. Therefore the students' dependency on Arabic literature on the subject is paramount. The study also shows that all the lecturers involved in the teaching of usul al-fiqh rely on literatures in Arabic and use them as their main textbooks. Thus this study concludes that the students' weakness in Arabic is the main challenge faced in the study of usul al-fiqh. To overcome this problem, serious long term actions must be taken by the Islamic faculties in the public universities to rectify this situation. Other than the above, this study further reveals that majority of the lecturers/tutors have not fully used Arabic as the medium as they have to explain and elaborate in Malay so that the students could properly understand the contents [2].

The level of Arabic command among students needs to be paid great attention. Due to the present level of Arabic command amongst students, lecturers focuses much of their attention either to explain the meaning of words and sentences or to translate the whole texts of relevant books. This is certainly a waste of valuable time that could be put to better use to deal with the subject matter in more depth.

We will try to examine the extent to which this content of fiqh is visible today.

\section{Ottoman period madrasah education}

As is known, religion continued its existence in the society in different forms since the creation of humankind and preserved its place as the basic factor in the formation of civilizations. Relatedly, importance has been given to religious education by all societies. Our purpose is not to emphasize the importance of religious education or display its history. Our purpose is to emphasize its importance in the geography we live. Religious education has been offered in madrasahs from Karahanlis and Seljukians in Anatolian soil, which dates back to $11^{\text {th }}$ and $12^{\text {th }}$ centuries.

In terms of foundation history, the structure of madrasah system was based on a legal foundation which was defined, interpreted and protected by fiqh science experts. In terms of organization, priority was given to fiqh and its auxiliary fields in the education offered at madrasahs [3]. Even before Nizamiye madrasahs, some madrasahs were founded to offer a fiqh-only education [4]. When we look at Anatolian Seljukian madrasahs, it can be seen that there was more specialization. Madrasahs were classified as daru'l-hadis, fiqh madrasah and medicine madrasah according to the topics covered. The Madrasah with Thin Minaret in Konya (1258) was a daru'l-hadis, Sırçalı Madrasah in Konya (1242) was a fiqh madrasah, and the eastern side of Double Madrasah in Kayseri was a medicine madrasah [5]. In this case, we can see that education in madrasahs was not single-sided based on religious education. E. İhsanoğlu explains the following concerning the first Ottoman madrasahs:

"Before Mehmed the Conqueror (Fatih), education in Ottoman madrasahs continued based on the tradition of Nizamiye Madrasahs with the basic purpose of covering religious sciences and popularization of fiqh education. However, the fact that some Seljukian madrasahs were founded next to hospitals and that there were observer wells next to some madrasahs gives some clues about the fact that astronomy and medicine were also studied in these madrasahs. Philosophical, mathematical and natural sciences which were not 
classified among religious sciences in Seljukian and pre-Fatih Ottoman period were studied in the houses of non-madrasah scientists or hospitals according to the traditions which continued since the past."

The abovementioned tradition continued without any degeneracy and by strengthening the education system in natural sciences. Indeed, the madrasah structure that Ottomans inherited from Seljukians showed considerable development in terms of curriculum and architecture. Fatih madrasahs constituted the infrastructure of the later Ottoman madrasahs.

In Ottoman madrasahs sciences called "Ulum-u 'aliye" (علوم عالية) such as kalam, logic, rhetoric, dictionary, syntax, mathematics, astronomy, philosophy, history and geography and sciences called "Ulum-u 'aliye" (علوم عالية) such as Qur'an sciences, hadith and fiqh were studied. After the reign of Suleiman the Magnificent, there were Umimi (General) madrasahs where Islamic sciences and the sciences which entered Islamic world later were studied and mudarrises, muftis and kadis were raised as well as Expertise Madrasahs which aimed at teaching one of the Islamic sciences or sciences that entered Islamic world later which were called Ulum-i Dahiliye (internal sciences) [6].

The mudarrises/scholars who lectured at these madrasahs were perceived as fatwa authorities of their region. They were seen as the first actors in such topics as funerals, marriages, divorces, condolences, inheritance, interpersonal disagreements, peace, shopping etc. From this perspective, madrasah scholars enjoyed a position which directed and executed social events. This is still the case. The fiqh knowledge which is covered theoretically at madrasahs is put into practice in such social topics as divorce, marriage, commerce and other disagreements. Therefore, the fiqh education provided is not restricted to the madrasah; it flows into life via mudarris and students.

In this case, student profile becomes important. Teaching period at madrasahs were mostly dependent on the diligence of students and their ability to pass required classes and exams; it was not organized based on the years and grades in today's sense. Students who studied the offered courses and passed the required exams with success were given a graduation certificate called "deed" which allowed the student to enter a high-degree madrasah. A student who was graduated from a high-degree madrasah with success was given a diploma which allowed for lecturing at any madrasah or working as kad1 [7]. Thus, although there was not a grade system in today's fashion, we can talk about the existence of exams which measured success and determined whether the student passed to a higher grade. It can be explained that this system was similar to the present system of passing from elementary school to secondary school, to university and then to master and $\mathrm{PhD}$ programs in order to complete the education at the highest level.

The education style which was formed before Ottomans continued at general measures in Ottoman period, too. Education and teaching activities continued at Ottoman madrasahs according to the level of students. It is known that in education book-passing was the principle, courses were recited with frequent repetitions and mutual negotiations and in the mosques or prayer rooms close to the classroom, the knowledge acquired was put into practice [8].

This order continued after the dissolution of Ottoman Empire including the courses delivered and textbooks covered; although they were not organized by a single institution, the same curriculum was followed in all madrasahs.

As a result, we can say that fiqh education and teaching constituted the foundation of this curriculum and covered an important place. In the examined madrasahs, fiqh books were the most widely used sources after the basic sources studied in order to ensure that Arabic, which is known as instrumental sciences, could be better understood. 


\section{Fiqh education at present imam hatip high schools}

Religious education in Turkey is offered on a formal and non-formal basis. Religious education is provided with religious culture and ethical knowledge courses which are compulsory until the end of high school education. In addition, students can obtain more knowledge about religion through prophetic biography, Qur'an-1 Qerim etc. courses which are provided on an elective basis at these grades. Similarly, there are İmam Hatip schools with their secondary and high school sections which focus on religious education. These schools offer field/vocational "must" courses such as Arabic, Qur'an, prophetic biography, fiqh and kalam in addition to the curricula of other schools which apply normal curriculum. In their high school period of eight years (four years secondary + four years) the students of İmam Hatip schools also receive scientific courses such as mathematics and chemistry as well as social courses such as history and geography and artistic courses like drawing and music which are covered in other schools. Here we can see that İmam Hatip high schools are not much different from Ottoman madrasah system structurally. Both religious and nonreligious sciences are covered in General Madrasahs in the same curriculum. However, considering the curriculum and its objectives, we can say that it is heading towards a slope compared to madrasah system. Yet, both schools produce specialized persons. These are individuals who can be assigned as Religious Culture teachers even on a contractual basis. Even if they cannot receive a task, they prefer Theology faculties.

Fiqh, which forms the backbone of basic Islamic sciences and is the most important course for expertise, is covered as fiqh and basic Islamic knowledge (catechism) at İmam Hatip high schools and an elective course with the title "readings in fiqh" is offered. The question is: is it adequate? When does this question emerge? Naturally, when the inadequacy of İmam Hatip high school graduates is observed in field courses.

Yes, it is a reality that the curriculum makes students inadequate. However, is this the only reason? As education is a whole consisting of curriculum, teacher and student, any problem in any one of them affects the other negatively. Students have difficulties due to the infrastructure problems in fiqh courses. In the system where Arabic language is not lectured adequately, they suffer from disconnection with Islamic sciences and they become unfamiliar with the terms and concepts in the course content, which suffocates students and drives them to despair.

In our country the age of religious education is unfortunately high; therefore, students who come from İmam Hatip schools see themselves as experts in religious matters. The religious groups which want to gain them also make some contributions as they take pains to keep in their monopoly the religious education of the person they influence. Due to this attitude, students question in their minds the religious group of the teachers before they begin the lecturing and feel sympathy or antipathy for the teacher according to the result.

In this case, it will not be true to argue that the only factor which creates the failure of the course to reach its objective is the curriculum.

\section{Fiqh education at universities}

Students graduated from Theology faculties work as İmam Hatip, preacher and mufti at different levels of Directorate of Religious Affairs, and teacher at public and private schools under the Ministry of National Education; but can they make the best of their duties?

Can the theology faculties which aim at equipping students with the knowledge and ability of reading and evaluating Islamic sciences from its resources, obtaining adequate knowledge in relevant social and religious sciences and relating them with their fields, expressing the things they learn in writing systematically, producing solutions to the 
problems they encounter concerning their field and sharing them with the society, and practicing vocational applications, obtain the efficiency that they target?

First of all, it should be noted that one of the most important factors is that students who come to theology faculties from İmam Hatip high schools come to theology faculties with the problems that we mentioned. Later, let us review the area that fiqh course covers in the curriculum of theology faculties.

In the course curriculum of theology faculties, Fiqh is offered in such courses as Islamic prayer principles, introduction to Islamic law, Islamic law procedure I and II, and Islamic law I and II. When this course which is given as 18 credits in total is divided into grades, it is seen that it is inadequate in terms of conveying of fiqh, and is covered very superficially. As a matter of fact, successful students who want to have a master's degree in the field of fiqh can become successful in master's program without infrastructure preparation.

One of the missing points in fiqh education in theology faculties is that the relation of fiqh with non-religious sciences is not mentioned in the curriculum at all. Thus, the social and worldly dimension of fiqh obliges it to relate to non-religious disciplines. That is to say that fiqh procedures which is a methodology of fiqh in that it enjoys logical consistency, examines the origins of legal principles, imposes general principles related to high ideas, Islamic terminology and commands, and teaches the general concepts of law, is also fiqh philosophy. Usul al-fiqh (Principles of Islamic Jurisprudence) is undoubtedly a core and important discipline in shariah studies. The term usul al-fiqh is actually derived from two words; usul (singular of asl) and fiqh. Each of the words has its own meanings; either literal or technical. However the term usul al-fiqh could be defined as follows: "the principles by the use of which the mujtahid arrives at the legal rules through specific evidences". Therefore, this discipline directly concerns the mujtahidin, scholars who have the qualification and ability to exercise and deduce Islamic rulings from recognized sources of laws especially al-Qur'an and al-Sunnah. By having knowledge of primary sources of Islamic law, an establishment of Islamic rulings can be done by utilizing other recognized derivative sources. As far as Shariah studies in the higher institutes and universities are concerned, the introduction of usul al-fiqh in its curriculum is crucial. It is undoubtedly that mastery of this discipline is necessary, for it is a very basic principle in deducing Islamic rulings in Islam

Its social dimension keeps its relation with sociology and psychology alive. This means that in topics for which judgement is sought without research, meaning daily matters, judgement cannot be made and fatwa cannot be given. Fiqh produces solution to the problems of the society on an Islamic ground and the contribution of the case law to solution depends on the knowledge of the interpreter of Islamic law about his time and society. Such that as indicated by İbn Abidin the mufti who will give fatwa has to know the traditions of the time and the status of the society. Therefore, it is essential in terms of fiqh education that new areas such as Islamic law philosophy and Islamic law sociology are included in theology curricula.

\section{Conclusion}

Students who are graduated from İmam Hatip high schools are inadequate in their fields of expertise and they carry this inadequacy to the society.

İmam Hatip graduates who prefer theology faculties have overconfidence like "I know everything"; as a result, they are graduated from faculty with unsuccessful degrees. The successful students reach this level only with their own effort.

The credit of must courses in theology faculty curriculum is not adequate in order to complete fiqh education. The courses teaching the relation of fiqh with non-religious sciences is not given any place in the curriculum. This makes the education of an individual 
who is respectful to traditions, have a vision and is creative impossible and creates a mentality which is disconnected with the world they live in.

I tried to display that it is compulsory that the teaching of fiqh, which is one of the three pillars of basic Islamic sciences, begins in small ages, that the course curricula at İmam Hatip high schools should be reviewed and people who will become theologists should be educated, curricula which would consider and support the existing deficiencies and fiqh education should be given more space in the curricula in theology faculties and number of its credits should be increased.

It is imperative to move beyond an exclusively doctrinal, literal and inflexible approach to the teaching and learning experiences in Islamic law.

\section{References}

1. A. Sabri, Gusmaneli, The Using of Media in Learning Fiqh to the Islamic Education Department of Education and Teacher Faculty of IAIN Imam Bonjol Padang. J. AlTa' $\lim 22$ (2), 180 (2015)

2. N.N.A. Rahman, A.K. Ali, R. Ramli, M.S. Ismail, The Teaching And Learning Of Usul Al Fiqh In Public Universities In Malaysia: Reality And Challenges, Shariah J. 16, 535 (2008)

3. E. İhsanoğlu, Osmanlı Medeniyeti Tarihi, 1, 232 (1999)

4. Z. Kazıc1, Ana Hatlarıla İslam Eğitim Tarihi, 48 (1995)

5. İ. Kayaoğlu (1994). İslam Kurumları Tarihi, 2, 54 (1994)

6. Z. Kazıc1, İslâm Medeniyeti ve Müesseseleri Tarihi, 372 (2003)

7. Y. Sarıkaya, Medreseler ve Modernleşme, 36 (1997)

8. C. Baltac1, XV. ve XVI. Asırlar Osmanlı Medreseleri, 45 (1976) 